\title{
Columbia and Yale at odds about Felig
}

An unhappy scandal has rocked the departments of medicine at Columbia University and Yale University, has led to the resignation of the newly appointed chairman of the department of medicine at Columbia, Dr Philip Felig and has again raised accusations of plagiarism in the scientific literature.

The trouble, regarded as a tragedy for all concerned by members of the department of medicine at Columbia, was first reported by the New York Times last week. What follows is a chronology of the events of the past few years.

In December 1978, Dr Felig, then at the department of internal medicine at Yale, was sent by the New England Journal of Medicine a paper which had been submitted by Dr Jesse Roth from the National Institutes of Health with Dr Helena Wachslicht-Rodbard as co-author. The paper, entitled "Insulin binding in anorexia nervosa", was sent to Dr Felig as a referee and eventually returned to the New England Journal of Medicine where it was published in April 1979.

Early in 1979, Felig and his associate of five or six years, Dr Vijay Soman, submitted to the American Journal of Medicine a paper with essentially the same title as that of Roth, which was sent by the Editor to a group of referees which included Dr Roth.

The authors of the original paper recognized that some portions of the text of the Felig-Soman paper were identical with their own original and that an equation which became the basis for their own statistical analysis of their data was similarly identical. Dr WachslichtRodbard protested to the Editor of the American Journal of Medicine and later Roth protested to Felig, as a result of which Felig offered to withdraw the abstract of the paper already submitted to that year's FASEB meeting in Atlantic City, to reprimand Dr Soman, to amend his paper so as to acknowledge Roth's priority and to arrange that the paper should not be published until after Roth's had appeared, which was in April 1979 (New England Journal of Medicine 300, 882).

Meanwhile, Roth's colleague at NIH had written to Felig and to the Dean of Medicine at Yale suggesting that much of the data which was the basis for the collaboration between Dr Soman and Dr Felig might be suspect and asking for an audit of the laboratory's work. Even though Dr Felig had at the outset denied the possibility that there might be irregularities in his laboratory, he agreed to an audit and, according to Dr Roth, not to publish his paper until the audit had been completed. In the event, the audit was long delayed and Soman and Felig's paper was published in January 1980 (American Journal of Medicine 68, 66). Only by
February 1980 had the independent audit been carried out, revealing discrepancies between raw data and published accounts thereof. Whereupon Dr Soman admitted "fudging" data.

During this period, a Columbia search committee was seeking a new chairman for the department of medicine. In the autumn of 1979 , the search committee interviewed Dr Felig, decided to offer him the post and had completed negotiations with him for his removal from Yale to Columbia at the turn of the year. Since then, Dr Felig has been making periodic visits to Columbia, where he began work full-time at the beginning of the academic year in midJune, having by then moved to New York.

People at Columbia say that they do not dispute Dr Felig's explanation that the alleged plagiarism in the article submitted to the American Journal of Medicine may have arisen because Dr Soman had kept a copy of the article sent to Dr Felig for review and passed on to him. Equally, they say, Dr Felig may have submitted his referee's report to the New England Journal of Medicine on the basis of a draft prepared by Dr Soman. They emphasize that there are no grounds for disputing Dr Felig's statement that he was unaware of similarities between his paper to the American Journal of Medicine and the paper submitted to the New England Journal of Medicine.

The audit in February 1980 of the data compiled in Dr Felig's laboratory prompted a second and again external audit by Dr Jerrold Olefsky of the University of Colorado. By then, Dr Felig had asked that Dr Soman should write a letter declaring that he alone was responsible for such similarities as there may have been between the Roth paper and that submitted by Felig and Soman to the American Journal of Medicine and Soman was dismissed. The independent audit disclosed that of more than a dozen papers submitted in recent years from Dr Felig's laboratory involving collaboration with $\mathrm{Dr}$ Soman at least eight were under a cloud and that six were unsupported by raw data gathered in the usual way in laboratory notebooks.

In February 1980, however, Dr Felig had proposed that Dr Soman should be appointed as assistant professor in the department of medicine at Columbia University without, people at Columbia now say, disclosing that Dr Soman's work was under a cloud. Although the dean of the medical school, Dr Donald F. Tapley, was informed of the outcome of the second independent audit of the Felig paper in March this year, it is now said that Dr Tapley did not inform his colleagues at Columbia until July, when word of the alleged plagiarism had been spread about and when Columbia, with Dr Felig already

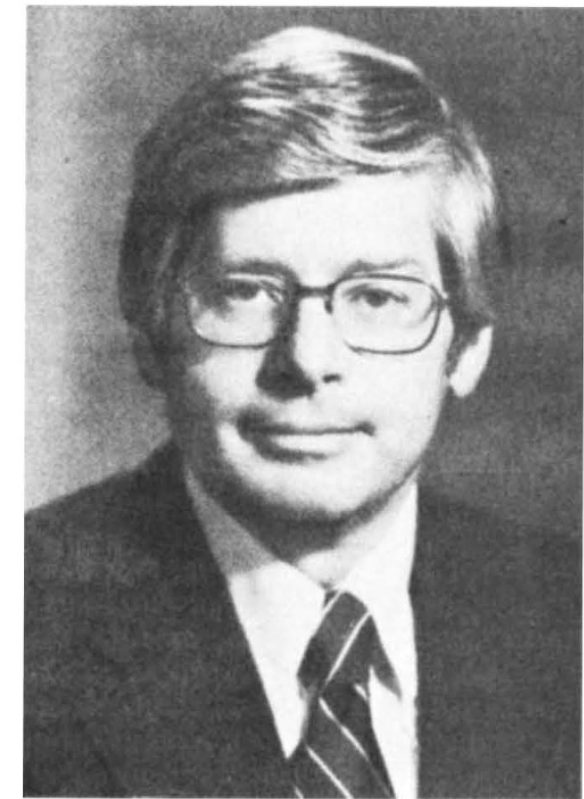

Dr Philip Felig

in post as chairman of the department of medicine, set up an ad hoc committee to look into the affair. During the early summer of this year, Dr Felig was at pains to deal with the consequences of the two independent audits.

One of the papers concerned in the investigation - Soman, V. and Felig, P. "Regulation of the glucagon receptor by physiological hyperglucagonaemia" was published in Nature $(272,829 ; 1978)$, and Dr Felig wrote to the Editor to say that it had not been possible to find the original data and that "until further data are available, the hormone binding data contained in that publication must be considered questionable". (Dr Felig had also written to the editors of several other journals in similar terms but a retraction in respect of another paper will appear in the current issue of the journal Diabetes. ) Dr Felig was told by Nature, in May, that in Dr Soman's interest it would be best if a retraction in respect of the Nature paper appeared only when the position had been cleared up.

In the event, the ad hoc committee at Columbia took the view that Dr Felig was at fault in not having been able to recognize similarities between the paper which he signed and submitted to the American Journal of Medicine and that which he had, a few weeks earlier, been asked to review; for having delayed for as much as nine months before seeing that an audit of his laboratory's data had been carried out; and for not volunteering to his academic colleagues at Columbia the trouble he had encountered at Yale. Faced with this complaint, Dr Felig resigned from Columbia at the end of last month.

Yale takes a quite different view of what has happened. On the telephone this week, 
Dr Robert W. Berliner said that Columbia had made a gigantic mistake. He said that the alleged plagiarism consisted of a sentence or two and an equation that is not nearly as special as is claimed. People at Yale, indeed, suspect that Dr Felig is the victim of a misunderstanding. He has been invited to return to Yale and has apparently agreed to do so. This week, Dr Felig was on vacation. Dr Roth, while sympathetic to the predicament in which Dr Felig initially found himself, expressed the view that it was careless of Dr Felig to go ahead with publication before the audit had been completed.

\section{School computing}

\section{Money to spend}

The British government's $£ 9$ million programme to promote the use of computers in schools is getting off to a slow start because of delays in appointing a director. To avoid the possibility of losing some of the money if it is not spent before next March, the Department of Education and Science (DES), which is putting up the funds, has already had to award some grants. About $£ 500,000$ of the $£ 1$ million set aside for this financial year has been either awarded or earmarked for projects which are as yet planned only in outline. The allocation of larger sums for projects which will define the emphasis of the fouryear programme will have to wait for the new director whose appointment is expected to be announced in September.

The present programme has grown out of a plan of the previous Labour government to spend $£ 12$ million on developing the educational value of microcomputers. None of that money was spent, however, because of the change of government in April last year. After more than a year of deliberation, the present Conservative government announced last March that it was to renew the programme by spending $£ 9$ million over the next four years: $£ 1$ million is to be spent before March 1981 and $£ 2.7$ million is to be spent in each of the remaining three years. When it is fully underway, the programme is to be administered by the Council for Educational Technology for the United Kingdom.

The DES has yet to decide on the overall objectives of the programme because to do so it needs the advice of the director as well as a recently appointed advisory committee of civil servants, teachers and representatives of educational organizations. The advisory committee gave the matter some thought at its first meeting at the end of July. All members were agreed that the programme should aim to improve the use of computers in schools but there was a difference of opinion on what should be the long-term objectives of computer education. Some members believe that the aim should be to acquaint most school leavers with computers and their uses: others believe that the aim should be to give pupils a grounding in programming and computer technology. Members plan to resolve the issue at the committee's next meeting in September.

Much of the work on computers in schools has been done by the Council for Educational Technology for the United Kingdom, which will administer the current programme when it gets under way. Other groups, which will no doubt be looking for funds, include Micro and Mini Computer Users in Secondary Education, a voluntary organization which is building up a library of software and guidance notes for teachers, and the Schools Council. The Schools Council hopes to receive grants to extend its existing work on compiling software and course notes on several subjects central to the school curriculum. Some of the packages it has already produced are designed to be of use in teaching history, economics, geography and even home heating, as well as chemistry, physics and biology.

Only about one hundred schools in Britain own their own computer and it is unlikely that much of the $£ 9$ million will be spent directly on increasing that number. One major constraint on the work funded under the programme will be that it should lead to results or suggestions for computer use which are within the financial limits of local education authorities.

Judy Redfearn

\section{Soviet environment}

\section{Old hands back}

Environmental protection is now a major feature of Soviet planning, and Moscow radio recently took to task Western newspapers (including the Guardian) which, it said, reported only the negative aspects of Soviet ecology. In response, the commentator drew specific attention to a speech of Academician N.P. Dubinin, delivered at this year's plenary meeting of the Soviet Academy of Sciences, and which was later published in the Vestnik of the Academy.

Academician Dubinin is a leading Soviet geneticist, whose work, notably his book Evolutionary Genetics had been

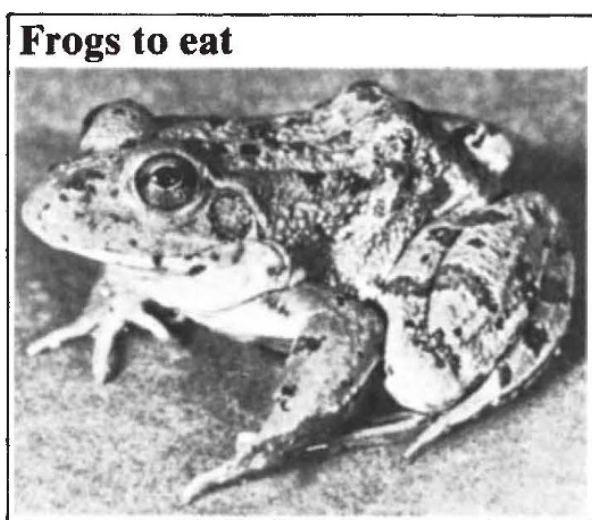

suppressed during the Lysenko period. His address to the academy, entitled Genetics and its significance for Mankind covered a whole range of topics from plant-breeding to genetic engineering. Nearly half his speech, however, was devoted specifically to the genetic aspects of pollution, which, he explained, make up an important section of the Soviet Union's "Man and biosphere" programme, which is the responsibility of a special environmental Interdisciplinary Council of the State Committee of the USSR on science and technology.

In his speech, Dubinin stressed that much of the work in this field was taking place within the framework of the United States - USSR collaboration programme. By stressing the collaborative aspect, he was thus able to quote exclusively from US sources on the genetic hazards of pollution by mutagens, or to attribute to American authors the more pessimistic viewpoint that "at the present time science does not have at its disposal the means of solving this exceptionally complex problem'". On the other hand he attributes to Soviet authors a "highly promising express test scheme" for studying the frequency of genetic mutation, tests based on leukocyte cultures and a method for determining gene and chromosome mutations in embryo mouse cells. The American J. V. Neel, however, receives due credit for his improved monitoring programme for observing the increase of mutations due to the Hiroshima and Nagasaki bombs.

In a speech intended to review the positive aspects of Soviet genetics, open criticism of past policy would clearly be out of place. There were, however, one or two, interesting allusions to the Lysenko aberration. In speaking of the "adaptive norm", Dubinin specifically cited his own (erstwhile banned) work of 1948, and stressed the importance of establishing whether or not unfavourable genetic changes had occurred over the last 20 to 30 years. Soviet genetics, it should be recalled was effectively restored only in $1963-64$. In a speech which the Soviet media singled out as the proper and positive way to report environmental genetics, such low-key criticisms, it appears, are quite in order.

Vera Rich

The edible frog (Rana esculenta), the basis of a number of French recipes for gourmets, is one of the species widespread on the mainland of Europe which have established themselves only with difficulty in the United Kingdom. The photograph is taken from a Nature Conservancy Council booklet, Wildlife Introductions to Great Britain, which is the report of a working party of the UK Committee for International Nature Conservation. The edible frog is apparently now established only in the counties of Norfolk and Sussex. 